\title{
Chronic stress promotes glioma cell proliferation via the PI3K/Akt signaling pathway
}

\author{
ZI-QIAN ZHANG ${ }^{1,2^{*}}$, XUE WANG $^{2 *}$, BING-HUA XUE $^{2}$, YUN ZHAO $^{2}$, FANG XIE $^{2}$, \\ SHI-DA WANG ${ }^{2}, \mathrm{CONG} \mathrm{XUE}^{2}$, YING WANG ${ }^{2}$, YAN-SHU ZHANG ${ }^{1}$ and LING-JIA QIAN ${ }^{2}$ \\ ${ }^{1}$ Laboratory Animal Center, North China University of Science and Technology, Tangshan, Hebei 063210; \\ ${ }^{2}$ Department of Stress Medicine, Institute of Basic Medical Sciences, Beijing 100850, P.R. China
}

Received February 3, 2021; Accepted June 10, 2021

DOI: $10.3892 /$ or.2021.8153

\begin{abstract}
High malignancy and high mortality of glioma render it urgent to elucidate the underlying mechanisms of glioma carcinogenesis and explore novel targets for therapy. Epidemiologic and clinical studies have revealed that chronic stress promotes the progression of various solid tumors and is correlated with poor prognosis; however, findings reporting the involvement of chronic stress in glioma are rare. In the present study, a chronic restraint animal model and a chronic stress cell model were established to explore the effects of chronic stress on glioma and its molecular mechanisms. The results revealed that chronic stress promoted glioma growth in vivo, and the serum levels of the stress hormones glucocorticoid (GC) and noradrenaline (NE) were significantly increased. In addition, GC and NE were verified to accelerate the proliferation of glioma cells in vitro. Mechanistically, the phosphatidylinositol 3-kinase (PI3K)/Akt signaling pathway was revealed to be activated under stress conditions, and inhibition of the expression of p-Akt could restrain the stress hormone-induced glioma cell proliferation. In addition, our data indicated that the GC receptor $(\mathrm{GR})$ and $\beta$-adrenergic
\end{abstract}

Correspondence to: Professor Yan-Shu Zhang, Laboratory Animal Center, North China University of Science and Technology, 21 Bohai Road, Tangshan, Hebei 063210, P.R. China

E-mail: yanshu_zhang@163.com

Professor Ling-Jia Qian, Department of Stress Medicine, Institute of Basic Medical Sciences, 27 Taiping Road, Beijing 100850, P.R. China E-mail: newjia@vip.sina.com

*Contributed equally

Abbreviations: GC, glucocorticoid; NE, noradrenaline; PI3K, phosphatidylinositol 3-kinase; GR, glucocorticoid receptor; MR, mineralocorticoid receptor; ADRA, $\alpha$-adrenergic receptor; ADRB, $\beta$-adrenergic receptor; HPA, hypothalamic-pituitary-adrenal; SNS, sympathetic nervous system; FBS, fetal bovine serum; DMSO, dimethyl sulfoxide; $\mathrm{SD}$, standard deviation; $\mathrm{MR}$, mineralocorticoid receptor

Key words: glioma, chronic stress, GC, NE, Akt, cell proliferation receptors (ADRBs) were both required for the biological functions of GC and NE in glioma cells. In conclusion, these results indicated that chronic stress and the stress hormones GC and NE activated PI3K/Akt signaling through binding to GR and ADRBs, thereby promoting glioma cell growth. Our findings may provide potential therapeutic targets and pave the way for the development of new strategies to protect patients with glioma from the detrimental effects of stress on tumor progression.

\section{Introduction}

Malignant glioma is the most common primary intracranial tumor, accounting for approximately $80 \%$ of central nervous system malignancies (1). At present, the treatment of glioma is still mainly based on surgical tumor removal supplemented by radiation therapy, chemotherapy, and other comprehensive treatment methods (2). Glioma is characterized by rapid proliferation, aggressive growth, and strong cellular heterogeneity $(3,4)$, which is the main reason why glioma is difficult to remove completely by surgery and why glioma is associated with high recurrence rates and poor prognosis. There are numerous measures of glioma prognosis, such as overall survival (OS) at one year, progression-free survival, and median survival. Of these, median survival is the most common and widely accepted metric for establishing the prognosis of glioma multiforme. The median survival of patients with glioblastoma multiforme (5-8), the most malignant glioma, is only 1 to 2 years (9). Therefore, it is urgent to investigate the regulatory mechanisms of glioma growth and explore new therapeutic targets.

Patients with cancer suffer from mental and physical stress, which causes an adverse stress response in the body and seriously affects clinical treatment and prognosis. Epidemiologic and clinical experimental studies have revealed that chronic stress can promote the progression of tumor and is closely related to poor prognosis (10-12). The hypothalamic-pituitary-adrenal (HPA) axis and the sympathetic nervous system (SNS) are activated by chronic stress, which is characterized by increased secretion of glucocorticoid (GC) and catecholamines (13). Numerous studies have revealed that GC signaling activation may contribute to progression of solid tumors, primarily through i) inducing anti-apoptosis activity 
and chemotherapy resistance and ii) disrupting antitumor immunity (14-16). It has been reported that the catecholamines, especially noradrenaline (NE), can alter downstream signaling pathways by binding to membrane receptors and are involved in the regulation of tumor growth. It has been revealed that NE binds to $\beta$-adrenergic receptors (ADRBs) and activates the cAMP/PKA signaling pathway in various cancers, such as ovarian, prostate, and pancreatic cancer (17-20). Propranolol, an ADRB inhibitor, has been demonstrated to inhibit tumor growth and metastasis $(21,22)$, which provides a new strategy for the treatment of tumors. In addition, catecholamines can also directly promote cancer cell proliferation through $\alpha$-adrenergic receptors (ADRAs) (23). However, findings reporting the involvement of chronic stress in glioma are rare.

Numerous studies have revealed the changes of some genes and signaling pathways involved in the occurrence and development of glioma. The predominant signaling pathways involved in glioma cell regulation include the RAS/RAF/ERK pathway, the p53/MDM2/p21 pathway, and the phosphatidylinositol 3-kinase (PI3K)/Akt/mTOR pathway (24-26). Studies have revealed that inhibition of PI3K/Akt signaling can increase autophagy levels of tumor cells, and thereby restrain cell proliferation and induce apoptosis (27-29). Akt, also known as protein kinase $\mathrm{B}$, is one of the most important downstream target kinases in the PI3K signal transduction pathway. It is in the central link of the PI3K/Akt pathway, and thus it plays an important role in a series of biological activities such as apoptosis, survival, and proliferation (30). However, there are few studies on the regulatory effects of the PI3K/Akt signaling pathway on the chronic stress-induced proliferation of gliomas.

In the present study, the effect of chronic stress on the malignant behavior of glioma was explored and its accelerative role in glioma cell proliferation was elucidated. To investigate whether chronic stress and stress hormone-induced glioma cell proliferation are regulated by the PI3K/Akt signaling pathway in vivo and in vitro, chronic stress animal experiments and cytological experiments were used. The present study was performed to investigate the targets and molecular mechanisms of chronic stress in regulating glioma progression and to provide new targets for the treatment of glioma.

\section{Materials and methods}

Animal model. A total of 10 male BALB/c nude mice (6-8 weeks old; weight, $\sim 18 \mathrm{~g}$ ) were used in the present study. The feeding conditions were as follows: Temperature, $18-22^{\circ} \mathrm{C}$; relative humidity, 50-60\%; 10-14 h light/dark cycle. Feed was added 3-4 times a week and water was changed 2-3 times a week. All of the animal experiments were approved (approval no. 2016-0002) by the Institutional Animal Care and Use Committee of the Academy of Military Medicine Sciences (Beijing, China). The experimental group was divided into the chronic restraint stress group and the control group, with 5 rats in each group. A restraint stress procedure was adopted based on previous studies $(17,31)$. The animals in the stress group were subjected to restraint adaptation for 1 week, which was gradually extended to $6 \mathrm{~h}$ per day. Next, U87MG glioma cells were injected subcutaneously into the mice of both groups at $2 \times 10^{6}$ cells per mouse. Then, the stress group was subjected to restraint stress for 21 days, $6 \mathrm{~h}$ per day ( 9 am to $3 \mathrm{pm}$ ). Since the restrained group could not eat and drink normally during restraint, the control mice were also deprived of water and food during the restraining period. The animals in the control group were also treated with water and food deprivation during the restraint period. The health and behavior of animals were monitored and observed every Wednesday and Saturday at 9 a.m. The checks included the growth of the xenograft (measurement of tumor size), the general condition of the mice (weight and mental status), abdominal breathing (breathing rate), and paw and toe characteristics (whether the paws and toes had fight damage). Adequate food and water was ensured and mice were sacrificed after 5 weeks. The specific criteria for euthanasia applied in this experiment were according to the Guidelines for the Review of Humane Endpoints in Animal Experiments (GB/T1.1-2009; www.chinesestandard.net/PDF. aspx/GBT1.1-2009); rapid cervical dislocation for euthanasia when the tumor metastasizes or grows rapidly to the point of ulceration, causing infection or necrosis, and observation of the experimental mice for two to three min without voluntary respiration and no blink reflex, was considered as having succumbed. The tumor samples were collected and embedded in paraffin for subsequent analysis.

Cell culture and intervention. The glioma cell lines U87MG and LN229 were purchased from the Chinese National Infrastructure of Cell Line Resource. U87MG cells were cultured in MEM (Sigma-Aldrich; Merck KGaA) medium containing 10\% fetal bovine serum (FBS; Gibco; Thermo Fisher Scientific, Inc.), $100 \mathrm{U} / \mathrm{ml}$ penicillin, $100 \mathrm{U} / \mathrm{ml}$ streptomycin, and $100 \mu \mathrm{g} / \mathrm{ml}$ nonessential amino acids. LN229 cells were cultured in DMEM (Sigma-Aldrich; Merck KGaA) medium containing $10 \%$ FBS, $100 \mathrm{U} / \mathrm{ml}$ penicillin, and $100 \mathrm{U} / \mathrm{ml}$ streptomycin. All cells were cultured in a humidified incubator containing $5 \% \mathrm{CO}_{2}$ at $37^{\circ} \mathrm{C}$. U87MG cells were used as 'glioblastoma of unknown origin' and identified by short tandem repeat analysis.

Stress hormones (GC and NE), an Akt-specific inhibitor (perifosine), or receptor antagonists were added to the culture medium for intervention. Based on successful activation/inhibition in previous publications $(32,33)$, the concentrations of all drugs were selected as follows: GC $(10 \mu \mathrm{mol} / \mathrm{l})$, NE $(10 \mu \mathrm{mol} / \mathrm{l})$, perifosine $(10 \mu \mathrm{mol} / \mathrm{l}$; cat. no. S1037), eplerenone [mineralocorticoid receptor (MR) antagonist, $5.2 \mu \mathrm{mol} / 1$; cat. no. S1707], mifepristone (GR receptor antagonist, $5.2 \mu \mathrm{mol} / 1$; cat. no. S2606), phentolamine (ADRA antagonist, $0.2 \mu \mathrm{mol} / 1$; cat. no. S2038), propranolol (ADRB antagonist, $24 \mu \mathrm{mol} / 1$; cat.no. S4076), atenolol (ADRB1 antagonist, $0.5 \mu \mathrm{mol} / 1$; cat. no. S4817), and higenamine hydrochloride (ADRB2 antagonist, $1.4 \mu \mathrm{mol} / 1$; cat. no. S3960). An equal volume of dimethyl sulfoxide (DMSO) was used as the control. The inhibitor and antagonists were purchased from Selleck Chemicals.

Immunohistochemistry. Hematoxylin-eosin (H\&E) staining and immunohistochemistry were performed as previously described (28). Briefly, paraffin-embedded sections were deparaffinized in xylene and rehydrated, followed by antigen retrieval in sodium citrate. After blocking with $1 \%$ BSA (BioFroxx), the sections were incubated with anti-Ki67 (1:200; 
cat. no. A11005) and anti-p-Akt (1:100; cat. no. AP0004; both from ABclonal Biotech Co., Ltd.) overnight at $4^{\circ} \mathrm{C}$. A DAB kit (ZLI-9018; ZSGB-BIO; OriGene Technologies, Inc.) was utilized to stain until the desired stain intensity was developed. Sections were then counterstained with hematoxylin, dehydrated, and mounted.

ELISA. Serums were collected from the stressed mice and the control mice. The serum concentrations of GC and NE were determined using a mouse GC ELISA kit (cat. no. D721183) and a mouse NE ELISA kit (cat. no. D751020; both from Sangon Biotech, Co., Ltd.), respectively, following the manufacturer's instructions. The ELISA kits were purchased from Shanghai Guduo Biological Technology Co., Ltd.

Colony formation assay. Glioma cells were inoculated into a 6-well plate at 2,000 cells/well. GC, NE, Akt signaling inhibitor, or DMSO was added and the culture solution was changed every 3 days. After culturing for 7-10 days, the cells were fixed with $2 \mathrm{ml}$ of $4 \%$ paraformaldehyde for $15 \mathrm{~min}$ at $4^{\circ} \mathrm{C}$ and stained at room temperature with $10 \%$ crystal violet solution for $30 \mathrm{~min}$. The colonies with $>10$ cells were counted under a low-power light microscope and representative images were captured.

Cell Counting Kit-8 (CCK-8) assay. Cells in logarithmic growth phase were inoculated into a 96-well plate at 500 cells/well in quintuplicate and incubated. After the cells adhered to the wall, GC, NE, inhibitors, and antagonists were added. After continuous culture for 0,24 , and $48 \mathrm{~h}$, the drug-containing medium was discarded, and freshly prepared solution containing $10 \mu \mathrm{lCCK}-8$ (Dojindo Molecular Technologies, Inc.) was added into each well. After incubation at $37^{\circ} \mathrm{C}$ for $1 \mathrm{~h}$, the $\mathrm{OD}$ value at $450 \mathrm{~nm}$ was measured by an enzyme mapping instrument (Varioskan Flash; Thermo Fisher Scientific, Inc.). The experiment was repeated three times.

Cell cycle experiment. The cells were digested to single cells and centrifuged at $1,000 \mathrm{rpm}$ for $5 \mathrm{~min}$ to collect cell precipitates. Then $70 \%$ ethanol was added and cells were fixed overnight at $4^{\circ} \mathrm{C}$. After washing with PBS, the cells were resuspended in $500 \mu \mathrm{l}$ PBS containing $50 \mu \mathrm{g} / \mathrm{ml} \mathrm{PI,} 100 \mu \mathrm{g} / \mathrm{ml}$ RNase A, and $0.2 \%$ Triton X-100 and incubated for $30 \mathrm{~min}$ at room temperature. Flow cytometry (CytomicsFC500; Beckman Coulter) was used to detect $20,000-30,000$ cells. The results were analyzed by cell cycle fitting software ModFit LT 4.1 (Verity Software House).

Western blot analysis. The cells were lysed in RIPA buffer (Biosharp) containing protease inhibitors and centrifuged at $12,000 \times \mathrm{g}$ for $15 \mathrm{~min}$ at $4^{\circ} \mathrm{C}$. The pellet was discarded and loading buffer (Tiangen Biotech Co., Ltd.) was added to the supernatant. Protein determination was performed by bicinchoninic acid assay. Samples were boiled for $5 \mathrm{~min}$ and proteins $(30 \mu \mathrm{g})$ were separated by 10 or $12 \%$ SDS-PAGE, followed by transfer to a PVDF membrane using a dry transfer system (Bio-Rad Laboratories, Inc.). The membrane was blocked in $5 \%$ milk at room temperature for $1 \mathrm{~h}$, washed 3 times in $1 \mathrm{X}$ TBST $\left(0.5 \%\right.$ Tween-20), and incubated at $4^{\circ} \mathrm{C}$ for $8 \mathrm{~h}$ with rabbit anti-PI3K $(1: 1,000$; product no. 4255 ;
Cell Signaling Technology, Inc.), rabbit anti-p-PI3K (1:1,000; product no. 13857; Cell Signaling Technology, Inc.), rabbit anti-Akt (1:1,000; cat. no. 51077-1-AP; ProteinTech Group, Inc.), mouse anti-p-Akt (1:1,000; cat. no. 66444-1-lg; ProteinTech Group, Inc.), or mouse anti-GAPDH (1:5,000; cat. no. 60004-1-lg; ProteinTech Group, Inc.). After washing three times in 1X TBST, membranes were incubated with HRP-labeled goat anti-rabbit IgG (1:5,000; cat. no. ZB-2301; ZSJQ-Bio) or goat anti-mouse IgG (1:5,000; cat. no. ZB-2305; ZSJQ-Bio) for $2 \mathrm{~h}$ at room temperature. Protein bands were visualized with an ECL western blotting substrate kit (Thermo Fisher Scientific, Inc.). The protein molecular weights of PI3K (110 kDa) and Akt (57 kDa) were so close to their corresponding phosphorylated proteins, p-PI3K (100 kDa) and p-Akt $(60 \mathrm{kDa})$, that the same protein strip needed to be washed with stripping buffer and then re-incubated with the antibody as well as exposed, followed by image acquisition and analysis by ImageQuant LAS 4000 (GE Healthcare Bio-Sciences; Cytiva).

siRNA transfection and quantitative $(q) P C R$. The siRNAs targeting ADRB1 and ADRB2 were synthesized by TsingKe Biological Technology. Sequences of siRNAs targeting ADRB1 were as follows: Sense, 5'-CCGAUAGCAGGUGAA CUCGAA-3' and antisense, 5'-GGCUAUCGUCCACUUGAG CUU-3'. Sequences of siRNAs targeting ADRB2 were as follows: Sense, 5'-CAGAGUGGAUAUCACAUGGAA-3' and antisense, 5'-GUCUCACCUAUAGUGUACCUU-3'. siRNA or siRNA negative control $(2.2 \mathrm{pmol})$ was diluted in $200 \mu \mathrm{l}$ of serum-free medium and mixed with a pipette. INTERFERin ${ }^{\circledR}$ (Polyplus transfection) reagent $(12 \mu \mathrm{l})$ was added, followed by vortex for $10 \mathrm{sec}$ and spinning twice. After $10 \mathrm{~min}$ of incubation at room temperature, the transfection mixture was added to the serum-containing medium and the cells were incubated for $48 \mathrm{~h}$ before performing the experiments, with the following groups: Ctrl group, siRNA negative control and siRNA group. For siRNA against Akt, the product Akt1/2 siRNA (h) (product no. sc-43609) was used, purchased from Santa Cruz Biotechnology, Inc. siRNA or siRNA negative control was diluted to $20 \mu \mathrm{mol} / 1$ with sterilized $\mathrm{ddH}_{2} \mathrm{O}$. The transfection mixture was added to serum-containing medium, and the cells were incubated for $12 \mathrm{~h}$ before performing the experiments with the following groups: Ctrl group, siRNA negative control and Akt1/2 siRNA (h) group. The siRNA negative control was purchased from TsingKe Biological Technology. Sequences of siRNA negative control were as follows: SiRNA negative control forward, 5'-UUCUCCGAA CGUGUCACGUTT-3' and reverse, 5'-ACGUGACACGUU CGGAGAATT-3'. Successful siRNA knockdown was verified by qPCR. Total RNA from cells or tissues was extracted using TRIzol reagent (Takara Biotechnology Co., Ltd.) according to the manufacturer's instructions. Reverse transcription (ABScriptII One Step RT-qPCR; Abclonal Biotech Co., Ltd.) reactions were performed with SYBR-Green. Real-time PCR was performed using a LightCycler 96 Real-time PCR System (Roche Diagnostics) with TB Green Premix Ex Taq kit (Takara Biotechnology Co., Ltd.). The thermocycling conditions were as follows: Initial denaturation at $95^{\circ} \mathrm{C}$ for $10 \mathrm{~min}$, denaturation at $95^{\circ} \mathrm{C}$ for $5 \mathrm{sec}$, annealing at $60^{\circ} \mathrm{C}$ for $30 \mathrm{sec}$ and extension at $72^{\circ} \mathrm{C}$ for $35 \mathrm{sec}$, for 40 cycles. $\beta$-Actin was used 
as the internal control. All samples were normalized to the internal controls, and fold changes were calculated via the relative quantification method $\left(2^{-\Delta \Delta \mathrm{Cq}}\right)$ (34). The primer sequences used were as follows: ADRB1 forward, 5'-GACGCTCACCAA CCTCTTCA-3' and reverse, ACTTGGGGTCGTTGTAGC AG; ADRB2 forward, 5'-TGATCGCAGTGGATCGCTAC-3' and reverse, 5'-CCACCTGGCTAAGGTTCTGG-3'; AKT1 forward, 5'-ACTGTCATCGAACGCACCTT-3' and reverse, 5'-TCGGAGCCCCCGAGTTG-3'; AKT2 forward, 5'-CCT CTGCAAAGAGGGCATCA-3' and reverse, 5'-GAGGAT GAGCTCGAAGAGGC-3'. $\beta$-actin forward, 5'-AATCGTGCG TGACATTAAGGAG-3', and reverse, 5'-ACTGTGTTGGCG TACAGGTCTT-3'.

Statistical analysis. All of the data are listed as the mean \pm standard deviation (SD). The continuous variables were evaluated for normality before comparison for statistical differences. Paired Student's t-tests were used for comparisons between two groups. One-way analysis of variance (ANOVA) was performed to compare the values among multiple groups. Significant results of ANOVA were subjected to Tukey's post hoc test. All of the differences were two-sided. Statistical analysis was conducted with GraphPad Prism 5.0 software (GraphPad Software, Inc.) and $\mathrm{P}<0.05$ was considered to indicate a statistically significant difference.

\section{Results}

Chronic stress promotes glioma growth in vivo, accompanied by an increase in serum GC and NE levels. To explore the effects of chronic stress on glioma growth, U87MG cells were subcutaneously injected into nude mice and a well-established chronic restraint stress model was adopted as previously described (17,31). Xenograft growth was monitored. The results revealed that the xenograft tumors in the stress group were larger than those in the control group at 4 weeks post-implantation (Fig. 1A). At 5 weeks post-inoculation, the tumors were removed and weighed, and the difference between the two groups was significant (Fig. 1B). Furthermore, although H\&E staining revealed no significant difference in the morphology of tumor tissues between the two groups (Fig. 1C), immunohistochemical staining revealed that the positive expression rate of Ki67 in the stress group was higher than that in the control group (Fig. 1D). Thus, the results indicated that chronic stress could enhance the tumor burden in the mouse model. As GC and NE are two of the most important stress hormones, their concentrations in the serum from control and stressed mice were examined. The serum levels of both GC and NE were higher in the chronic stress group (Fig. 1E).

GC and NE enhance glioma cell proliferation in vitro. To further characterize the role of chronic stress in regulating the malignant behavior of glioma cells, the stress hormones GC and NE were added to U87MG and LN229 cells in vitro. The CCK-8 assay was used to examine cell growth. Compared with the control group, the proliferation rate of the GC- and NE-treated cells was increased (Fig. 2A). Consistently, the results of the colony formation assay also revealed that the GC- and NE-treated cells formed more colonies (Fig. 2B). Furthermore, the cell cycle distribution was determined by flow cytometric analysis. The data revealed a decrease in $\mathrm{G}_{0} / \mathrm{G}_{1}$-phase cells and an enhanced S-phase transition after GC or NE intervention (Fig. 2C). Collectively, these results supported the theory that stress could accelerate glioma cell proliferation by increasing the concentrations of GC and NE.

PI3K/Akt signaling is activated by chronic stress. Considering $\mathrm{PI} 3 \mathrm{~K} / \mathrm{Akt}$ signaling is hyperactivated in various cancers and plays a critical role in cell proliferation and survival $(27,28)$, the influence of chronic stress on PI3K/Akt signaling was evaluated. Western blot results revealed that compared with the DMSO group, the expression levels of p-PI3K and p-Akt in U87MG and LN229 cells were increased after GC or NE intervention, indicating the PI3K/Akt pathway was activated (Fig. 3A). Moreover, the immunohistochemical results further confirmed that the positive expression rate of p-Akt in xenografts in stressed mice was higher than that in xenografts in control mice (Fig. 3B). The aforementioned results indicated that the PI3K/Akt signaling pathway may have a regulatory role in chronic stress-induced glioma proliferation.

Chronic stress promotes glioma cell proliferation via Akt signaling. To elucidate the role of Akt signaling in chronic stress-induced glioma cell proliferation, the Akt-specific inhibitor perifosine was used. Firstly, the influence of perifosine on the p-Akt levels was determined by western blot analysis. The results revealed that perifosine could effectively inhibit the expression of p-Akt (Figs. 4A and S1A). As anticipated, the reduction in p-Akt levels significantly inhibited the GC- and NE-induced growth and colony formation of U87MG and LN229 cells (Fig. 4B and C). In addition, the cell cycle analysis revealed an increased proportion of $\mathrm{G}_{0} / \mathrm{G}_{1}$-phase cells and a decreased proportion of S-phase cells upon treatment with GC or NE combined with perifosine compared with GC or NE treatment alone (Fig. 4D). Experiments using siRNA targeting Akt revealed the same results (Fig. S1B-D). The stress hormones GC and NE were able to promote the proliferation of glioma cells, while inhibition of the Akt signaling pathway significantly reduced the proliferation of glioma cells. Although inhibition of the Akt signaling pathway failed to completely eliminate the difference in proliferation between cells in the GC and $\mathrm{NE}$ groups and control cells, the ratio of GC + perifosine/DMSO + perifosine or $\mathrm{NE}+$ perifosine/DMSO + perifosine was decreased compared with that of GC/DMSO or NE/DMSO in the number of clones and S-phase cells (Fig. S2). In conclusion, these data indicated that inhibition of p-Akt expression, at least to some extent, inhibited stress hormone-induced glioma cell proliferation.

$G R$ and $A D R B$ s are required for $G C$ - and NE-mediated Akt activation and glioma cell proliferation. GC directly binds to MR or GR (35). Different antagonists were used to determine the receptor type that participates in the GC-mediated Akt activation and cell proliferation. Compared with the GC-treated group, the GR antagonist mifepristone could reduce the expression of p-Akt, while the MR antagonist eplerenone revealed no effect (Fig. 5A). Consistently, CCK-8 assay results revealed that mifepristone, but not eplerenone, 

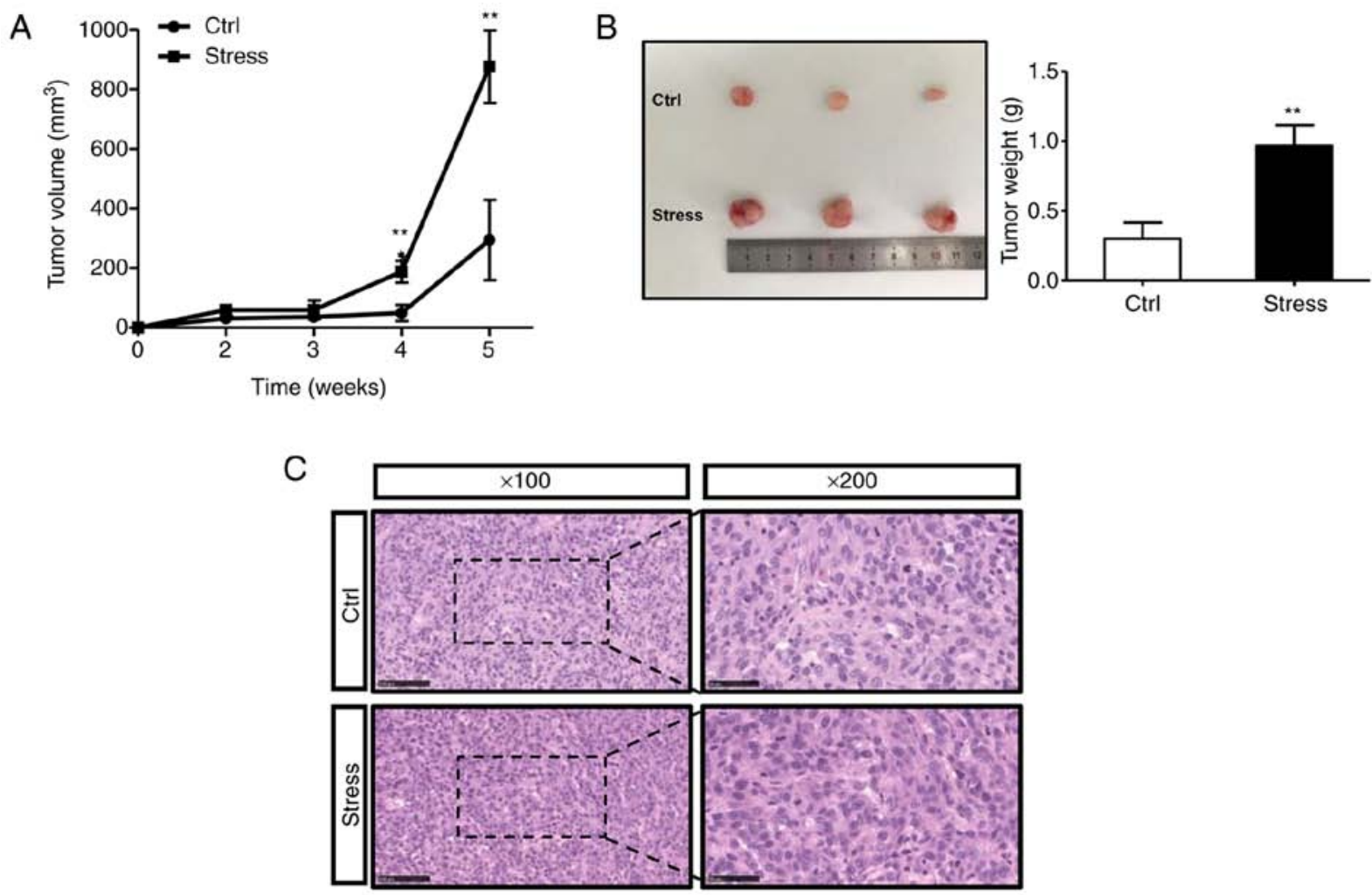

D
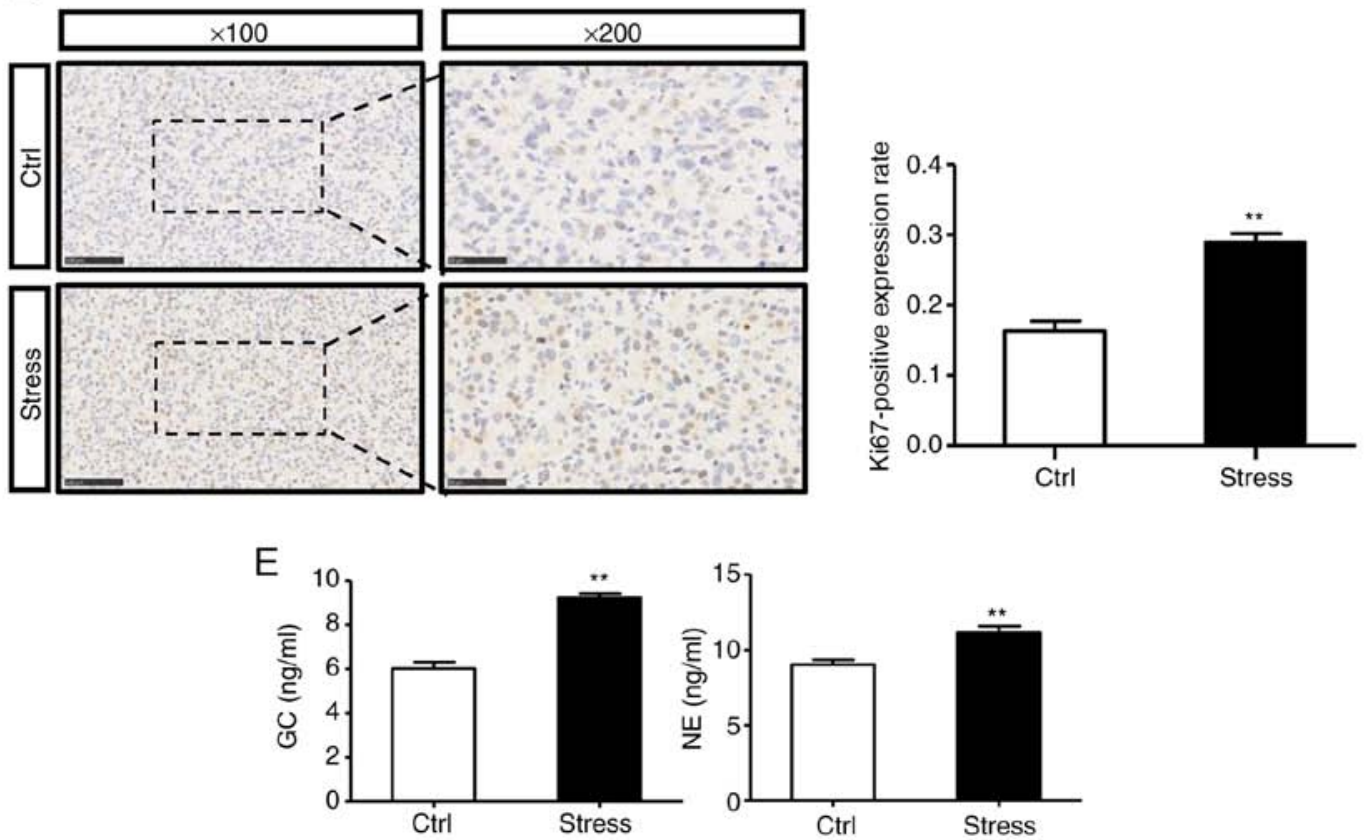

Figure 1. Chronic stress promotes glioma growth in vivo. (A) Xenograft tumor growth was monitored. (B) The weight of xenograft tumors from control and stress groups was compared. (C) Representative images of hematoxylin and eosin staining of xenograft tumors. Magnification, $\mathrm{x} 100$; scale bar, $100 \mu \mathrm{m}$. Magnification x200; scale bar, $50 \mu \mathrm{m}$. (D) Representative images of immunohistochemical staining of Ki67 in xenograft tumors. Magnification, x100; scale bar, $100 \mu \mathrm{m}$. Magnification, x200; scale bar, $50 \mu \mathrm{m}$. (E) Concentrations (ng/ml) of glucocorticoid and norepinephrine in serum of control and stress mice after sacrifice. Data are presented as the mean $\pm \mathrm{SD}(\mathrm{n}=3)$. ${ }^{* *} \mathrm{P}<0.01$. GC, glucocorticoid; NE, norepinephrine.

reduced the distinct growth capacity of U87MG and LN229 cells between the GC group and the DMSO group (Fig. 5B).

Adrenergic receptors are classified as ADRAs and ADRBs. The p-Akt expression levels and cell growth rate were evaluated under different antagonist treatments. The results revealed that propranolol, the antagonist targeting ADRBs, not only abrogated the activation of $\mathrm{p}$-Akt, but also abolished the discrepant glioma cell growth triggered by NE treatment (Fig. 6A and B). Considering ADRB1 and ADRB2 are the main ADRBs in glioma tissues (36), specific antagonists were further added. Lower p-Akt levels and reduced cell growth were observed in cells in which ADRB1 and ADRB2 were inhibited (Fig. 6C and D), suggesting both receptors are required for the biological function of $\mathrm{NE}$ in glioma cells. 

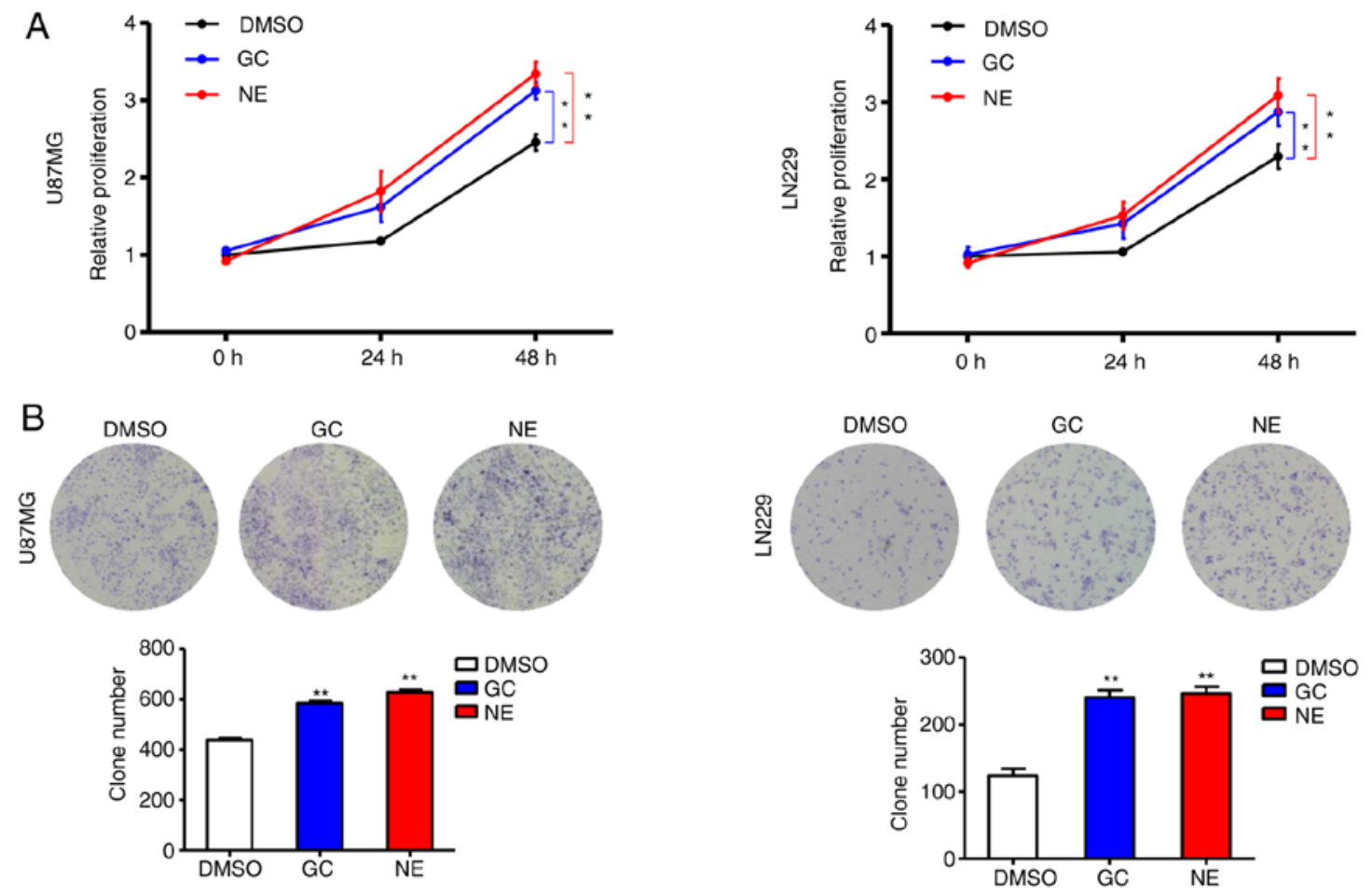

C
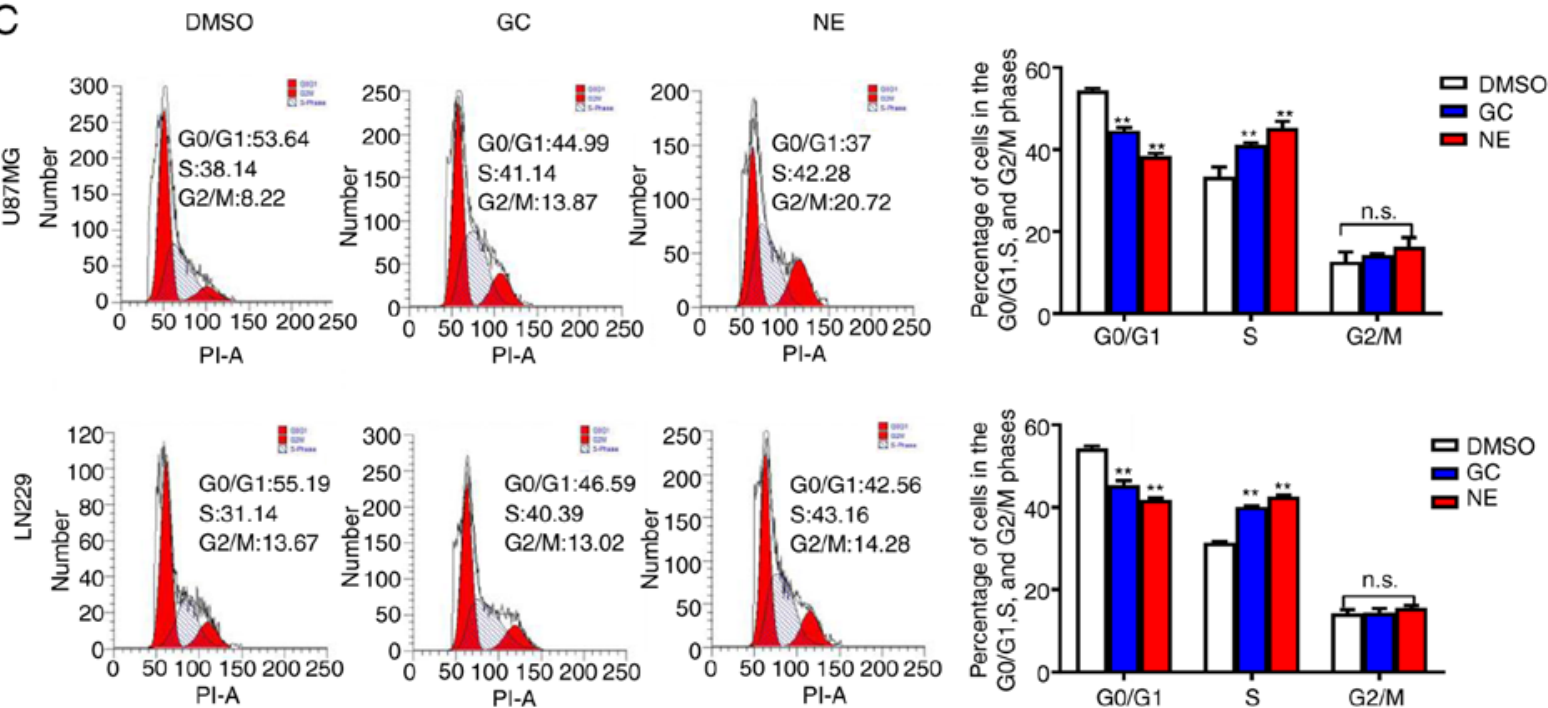

Figure 2. Stress hormones facilitate glioma cell proliferation. (A) Cell Counting Kit-8 results of U87MG and LN229 cells treated with GC (10 $\mu$ mol/1) or NE $(10 \mu \mathrm{mol} / \mathrm{l})$. (B) Representative images and statistical analysis of colony formation assays in U87MG and LN229 cells treated with GC or NE. (C) Cell cycle assay and statistical analysis of U87MG and LN229 cells treated with GC or NE. Data are presented as the mean \pm SD $(n=3)$. ${ }^{* *} \mathrm{P}<0.01$. GC, glucocorticoid; NE, norepinephrine; n.s., no significance.

Moreover, intervention with low concentrations of ADRB1 and ADRB2 antagonists alone and in combination revealed that the two drugs exerted synergistic effects (Fig. S3). Experiments using siRNA targeting ADRB1/2 confirmed these results (Fig. S4).

\section{Discussion}

Patients with cancer suffer from persistent mental and physical stress, which causes adverse stress reactions of the body and affects clinical treatment and prognosis. A large number of epidemiological investigations and clinical trials have revealed that chronic stress is closely related to the occurrence and development of a variety of tumors (37-39). However, findings reporting the involvement of chronic stress in glioma are rare. In the present study, it was revealed that chronic stress promoted glioma cell proliferation by activating PI3K/Akt signaling, indicating a stimulative role of chronic stress in glioma progression.

Periodic immobilization is a well-established chronic stress paradigm, in which stressed mice are restrained in a confined space that prevents them from moving freely or turning around but does not unduly compress them. This method has already been demonstrated to induce high levels of HPA axis and SNS activity characteristic of chronic stress $(21,40,41)$. Thus, this paradigm was adopted to evaluate the effect of chronic stress 
A
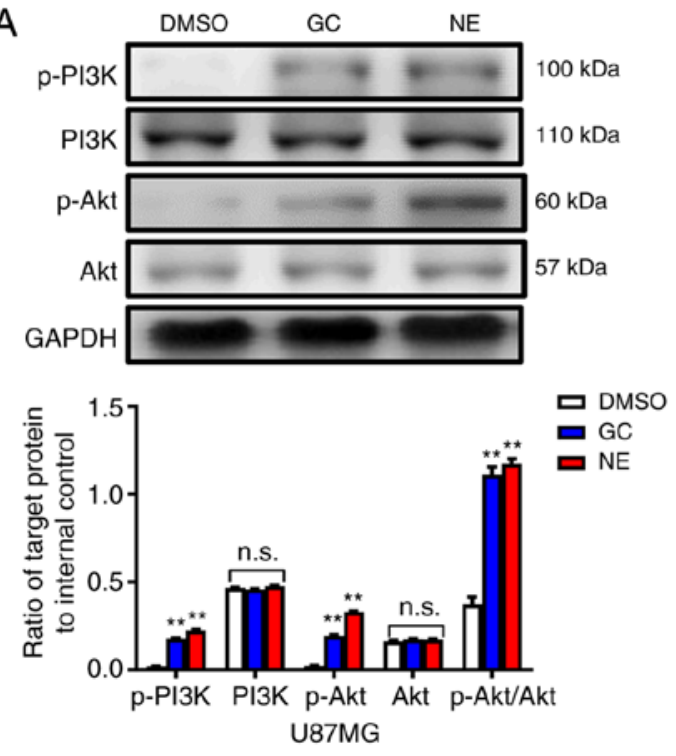

$\mathrm{B}$
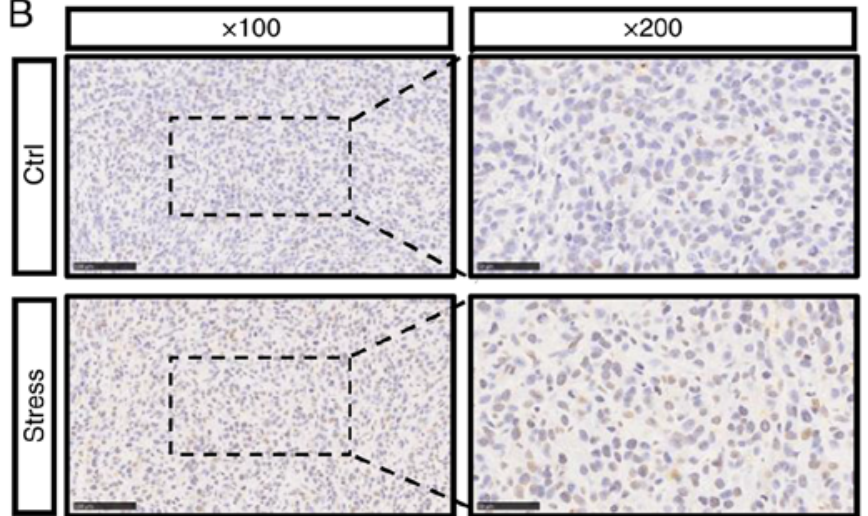
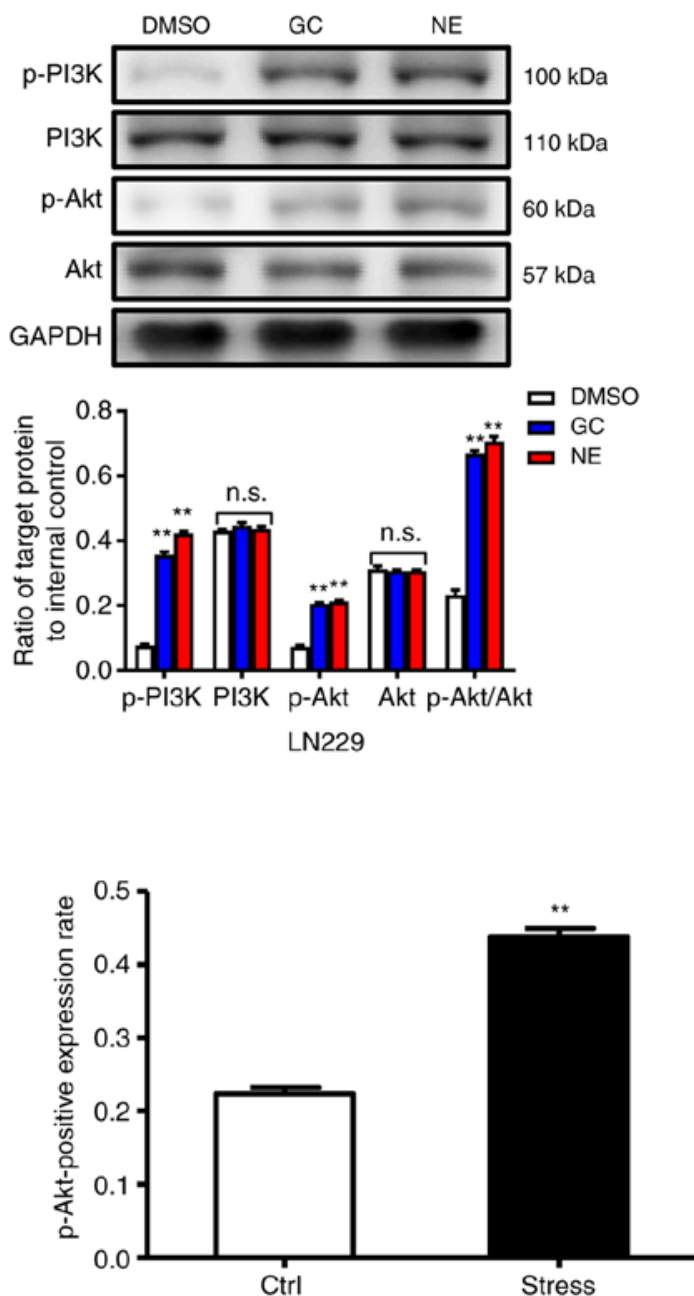

Figure 3. Chronic stress activates the PI3K/Akt signaling pathway. (A) Western blot assay and statistical analysis of PI3K/Akt signaling-related proteins in U87MG and LN229 cells treated with GC or NE. (B) Representative images and statistical analysis of immunohistochemical staining of p-Akt in xenograft tumors from control and stress mice. Magnification, $\mathrm{x} 100$; scale bar, $100 \mu \mathrm{m}$. Magnification, $\mathrm{x} 200$; scale bar, $50 \mu \mathrm{m}$. Data are presented as the mean $\pm \mathrm{SD}$ ( $\mathrm{n}=3$ ) ${ }^{* *} \mathrm{P}<0.01$. PI3K, phosphatidylinositol 3-kinase; GC, glucocorticoid; NE, norepinephrine; p-, phosphorylated; n.s., no significance.

on glioma growth in vivo. U87MG cells were injected subcutaneously into the mice, which were subjected to restraint stress for 21 days. It was revealed that the xenografts from the stressed mice exhibited enhanced tumor growth (larger size and higher weight). Consistently, the number of Ki67 ${ }^{+}$cells was significantly increased in the chronic stress group compared with that of the control group. These results indicated that chronic stress promoted glioma growth in vivo.

Chronic stress can induce aberrant persistent activation of the HPA axis and the SNS, leading to enhanced release of GC and the simultaneous elevation of catecholamine levels $(42,43)$. In the present study, it was also demonstrated that the serum levels of GC and NE in chronic stressed mice were increased compared with control mice. Numerous studies have reported that stress-induced hormones contribute to tumor progression through a number of important biological processes, such as exerting antiapoptotic effects, inducing chemotherapy resistance, and disrupting antitumor immunity (14,44-46). The concentrations of these stress-related hormones are $1 \mathrm{nmol} / \mathrm{l}$ in normal human circulation, reaching up to $100 \mathrm{nmol} / \mathrm{l}$ under stress conditions and $10 \mu \mathrm{mol} / 1$ in the tumor microenvironment (47). To further verify whether chronic stress has the same stimulatory effect on glioma proliferation in vitro, the glioma cell lines U87MG and LN229 were treated with the stress hormones GC and NE at $10 \mu \mathrm{mol} / \mathrm{l}$. The experimental results revealed that after intervention with stress hormones, the cell growth rate and clone number were significantly increased compared with the control group, and more cells were in the $\mathrm{S}$ phase. The aforementioned results were in agreement with the results of the animal studies, revealing that chronic stress also promoted glioma proliferation in vitro.

The activation of PI3K/Akt signaling can promote the proliferation of cancer cells and inhibit their apoptosis. Studies have revealed that inhibition of the activity of the PI3K/Akt signaling pathway can promote autophagy in tumor cells, thereby suppressing cell proliferation and inducing apoptosis $(29,46,48)$. Consistently, the PI3K/Akt signaling pathway can inhibit anticancer drug-induced autophagy in U87MG cells (49). In the present study, it was also revealed that inhibiting PI3K/Akt signaling decreased glioma cell growth, colony formation, and S-phase transition. However, whether the PI3K/Akt signaling pathway plays a regulatory role in the chronic stress-induced proliferation of glioma cells remains unclear. Herein, the changes in the levels of PI3K/Akt 

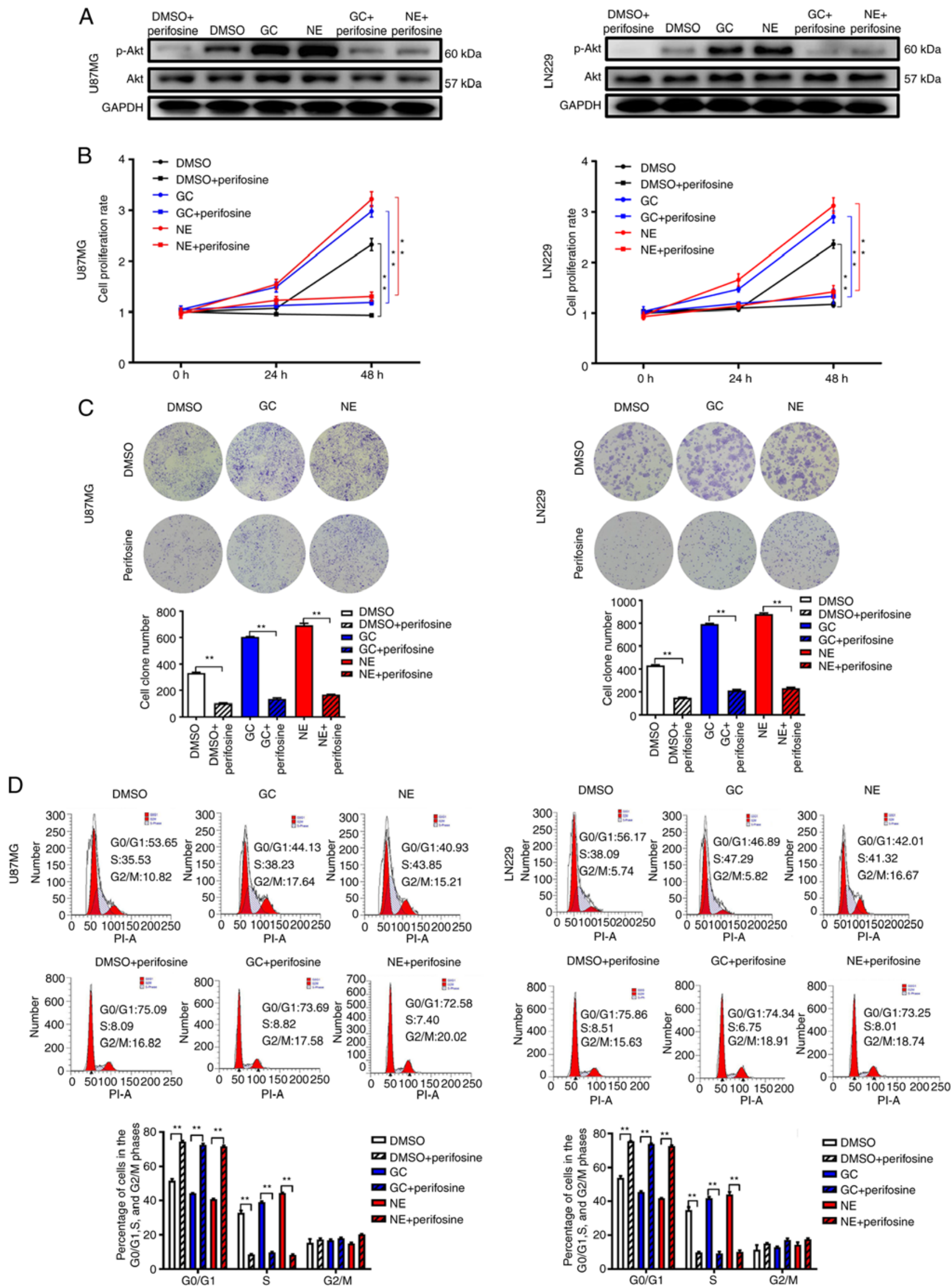

Figure 4. Inhibition of Akt signaling suppresses stress-induced glioma cell proliferation. (A) Western blot assay and statistical analysis of p-Akt levels in U87MG and LN229 cells treated with GC or NE with or without Akt signaling inhibitor (perifosine, $10 \mu \mathrm{mol} / \mathrm{l}$ ). (B) CCK8 results of U87MG and LN229 cells after the inhibition of Akt signaling. (C) Representative images and statistical analysis of colony formation assays in U87MG and LN229 cells after the inhibition of Akt signaling. (D) Cell cycle assay and statistical analysis of U87MG and LN229 cells after the inhibition of Akt signaling. Data are presented as the mean $\pm \mathrm{SD}(\mathrm{n}=3) .{ }^{* *} \mathrm{P}<0.01$. $\mathrm{p}$-, phosphorylated; GC, glucocorticoid; NE, norepinephrine. 

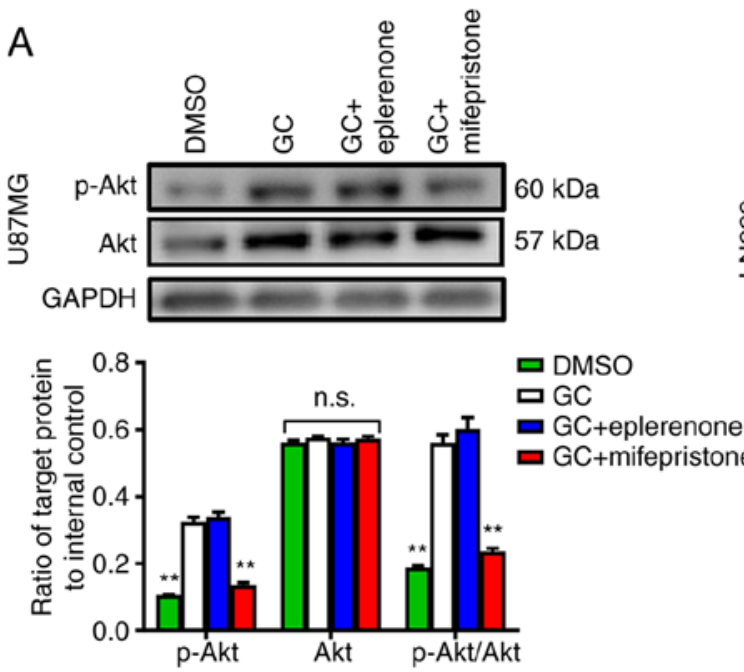

B

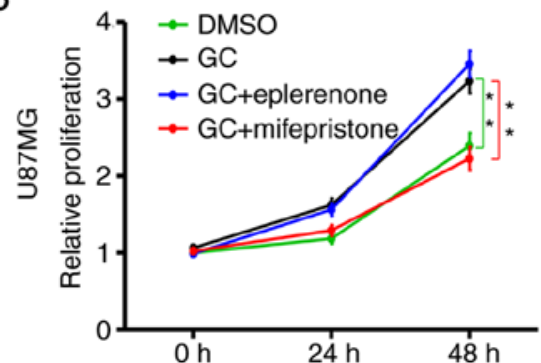




Figure 5. GR contributes to GC-enhanced glioma cell proliferation. (A) Western blot assay and statistical analysis of p-Akt levels in U87MG and LN229 cells treated with GC with or without MR antagonist (eplerenone, $5.2 \mu \mathrm{mol} / \mathrm{l}$ ) or GR antagonist (mifepristone, $5.2 \mu$ mol/l). (B) Cell Counting Kit-8 results of U87MG and LN229 cells with indicated treatment. Data are presented as the mean $\pm \mathrm{SD}(\mathrm{n}=3) .{ }^{* *} \mathrm{P}<0.01$. GR, glucocorticoid receptor; GC, glucocorticoid; p-, phosphorylated; MR, mineralocorticoid receptor; n.s., no significance.

signaling-related proteins upon chronic stress in vitro and in vivo were detected by western blotting and immunohistochemical assays. The results revealed that the signaling pathway was activated. Furthermore, perifosine, an Akt inhibitor, was used to block the pathway in vitro. Functional assays revealed that in U87MG cells, the number of clones increased up to 1.81-fold after GC treatment compared with the control, whereas after inhibition of Akt signaling, the number of GC-induced clones increased only 1.31-fold. In the cell cycle analysis, the number of S-phase cells increased to 1.25-fold after GC treatment compared with the control, while there was no proliferation trend of GC-induced S-phase cells compared with the control after inhibition of Akt signaling. Notably, similar results were obtained in LN229 cells and after NE treatment. In conclusion, these data indicated that inhibition of p-Akt expression, at least to some extent, suppressed stress hormone-induced glioma cell proliferation.

It has been reported that stress hormones are involved in the regulation of signaling pathways in tumor cells through binding to their receptors, among which GC primarily binds to GR (14), and NE has been revealed to combine with ADRA or ADRB $(23,50)$. Herein, in order to investigate which receptor is required for the biological effects of GC and NE in glioma, the hormone binding to the receptors was reduced by using receptor antagonists of the GC-related receptors GR and MR and the NE-related receptors ADRA and ADRB. The results of protein immunoblotting experiments demonstrated that GR and ADRB antagonists could effectively reduce the expression of p-Akt. Consistently, CCK- 8 results revealed that the two antagonists decreased the proliferation of glioma cells. Although the ADRBs can be divided into $\beta 1, \beta 2$, and $\beta 3$ receptors, studies have reported that glioma tissues mainly express $\beta 1-$ and $\beta 2$-adrenergic receptors $(35,51,52)$. Therefore, the $\beta 1$ - and $\beta 2$-receptors separately were further blocked. CCK- 8 results revealed that this reduced the proliferation of glioma cells, indicating that both receptors are required for the regulation of glioma cell growth by NE. Collectively, our data indicated that GC mainly bound to GR and NE bound to ADRB1 and ADRB2 to exert their biological effects in glioma. In clinical practice, patients with glioma are bound to suffer from negative emotions and stress due to the disease. Therefore, glioma treatment can be combined with surgery and targeted blockade of the PI3K/Akt signaling pathway or blockade of GC/NE signaling and their corresponding receptors GR/ADRBs to achieve a more desirable therapeutic effect. Nevertheless, the molecular mechanisms by which the PI3K/Akt signaling pathway is activated after binding of stress hormones to receptors remain unknown.

In summary, our experiments are the first to explore the ability of chronic stress and stress-induced hormones to promote glioma proliferation in vivo and in vitro. Mechanistically, GC and NE mainly bound to GR and ADRBs and further activated the PI3K/Akt signaling pathway. The findings of the present study may provide potential therapeutic targets and facilitate the development of new strategies to 

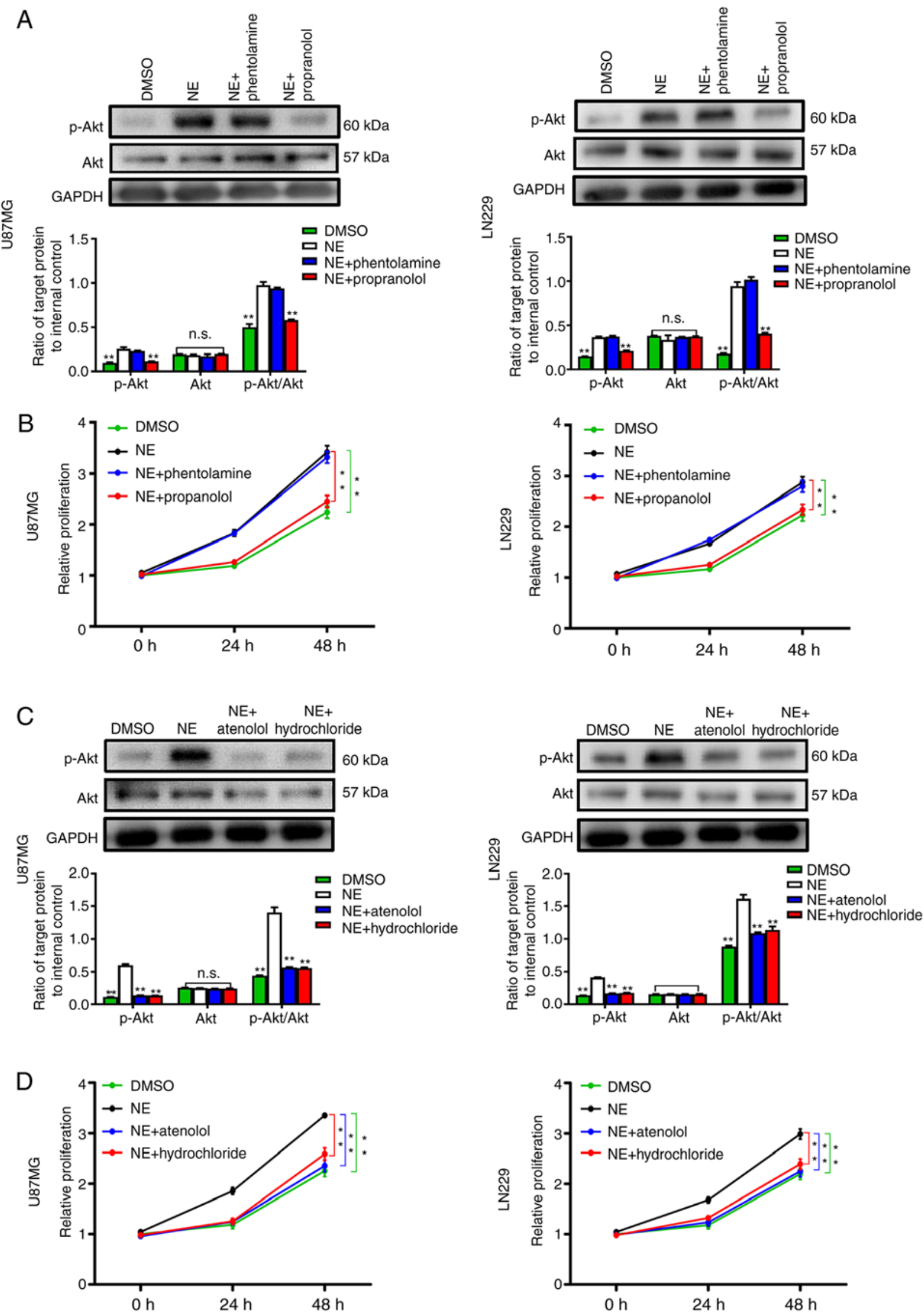

Figure 6. NE promotes glioma cell progression via ADRBs. (A) Western blot assay and statistical analysis of p-Akt levels in U87MG and LN229 cells treated with NE with or without ADRA antagonist (phentolamine, $0.2 \mu \mathrm{mol} / \mathrm{l}$ ) or ADRB antagonist (propranolol, $24 \mu \mathrm{mol} / \mathrm{l}$ ). (B) CCK-8 results of U87MG and LN229 cells after NE treatment with or without adrenergic receptor antagonists. (C) Western blot assay and statistical analysis of p-Akt levels in U87MG and LN229 cells treated with NE with or without ADRB1 antagonist (atenolol, $0.5 \mu \mathrm{mol} / \mathrm{l}$ ) or ADRB2 antagonist (hydrochloride, $1.4 \mu \mathrm{mol} / \mathrm{l})$. (D) CCK-8 results of U87MG and LN229 cells after NE treatment with or without ADRB antagonists. Data are presented as the mean $\pm \mathrm{SD}(\mathrm{n}=3) .{ }^{* *} \mathrm{P}<0.01$. NE, norepinephrine; ADRB, $\beta$-adrenergic receptor; p-, phosphorylated; ADRA, $\alpha$-adrenergic receptor; CCK-8, Cell Counting Kit-8; n.s., no significance. 
protect patients with glioma from the detrimental effects of stress on tumor progression. However, there are still shortcomings in our experiments, such as not considering the sample size adequately in order to adhere to the $3 \mathrm{R}$ principle of animal welfare (Reduction, Replacement, Refinement) (53), and thus the sample size will be increased accordingly to render the data more scientific and reliable when the same problems will be encountered in future experiments.

\section{Acknowledgements}

Not applicable.

\section{Funding}

The present study was supported (grant nos. 81702454, 31771290 and 31571173 ) by the National Natural Science Foundation of China.

\section{Availability of data and materials}

The datasets used and/or analyzed during the current study are available from the corresponding author on reasonable request.

\section{Authors' contributions}

ZQZ performed the experiments. ZQZ and XW analyzed and interpreted the data as well as critically revised the manuscript for important intellectual content. ZQZ performed the statistical analysis and drafted the manuscript. YSZ and LJQ provided administrative and technical support and also supervised the study. ZQZ, XW, BHX, YZ, FX, SDW, CX and YW contributed to the conception and design of the study. All authors read and approved the final manuscript and agree to be accountable for all aspects of the research.

\section{Ethics approval and consent to participate}

All of the animal experiments were approved (approval no. 2016-0002) by the Institutional Animal Care and Use Committee of the Academy of Military Medicine Sciences (Beijing, China).

\section{Patient consent for publication}

Not applicable.

\section{Competing interests}

The authors declare that they have no competing interests.

\section{Reference}

1. Ostrom QT, Gittleman H, Fulop J, Liu M, Blanda R, Kromer C, Wolinsky Y, Kruchko C and Barnholtz-Sloan JS: CBTRUS statistical report: Primary brain and central nervous system tumors diagnosed in the united states in 2008-2012. Neuro Oncol 17 (Suppl 4): iv1-iv62, 2015.

2. Chinot OL, Wick W, Mason W, Henriksson R, Saran F, Nishikawa R, Carpentier AF, Hoang-Xuan K, Kavan P, Cernea $\mathrm{D}$, et al: Bevacizumab plus radiotherapy-temozolomide for newly diagnosed glioblastoma. N Engl J Med 370: 709-722, 2014.
3. Cuddapah VA, Robel S, Watkins S and Sontheimer H: A neurocentric perspective on glioma invasion. Nat Rev Neurosci 15: 455-465, 2014.

4. Chen J, McKay RM and Parada LF: Malignant glioma: Lessons from genomics, mouse models, and stem cells. Cell 149: 36-47, 2012.

5. Gately L, McLachlan SA, Dowling A and Philip J: Life beyond a diagnosis of glioblastoma: A systematic review of the literature. J Cancer Surviv 11: 447-452, 2017.

6. Lacroix M, Abi-Said D, Fourney DR, Gokaslan ZL, Shi W, DeMonte F, Lang FF, McCutcheon IE, Hassenbusch SJ, Holland E, et al: A multivariate analysis of 416 patients with glioblastoma multiforme: Prognosis, extent of resection, and survival. J Neurosurg 95: 190-198, 2001.

7. Carlsson SK, Brothers SP and Wahlestedt C: Wahlestedt, Emerging treatment strategies for glioblastoma multiforme. EMBO Mol Med 6: 1359-1370, 2014.

8. Witthayanuwat S, Pesee M, Supaadirek C, Supakalin N, Thamronganantasakul K and Krusun S: Survival analysis of glioblastoma multiforme. Asian Pac J Cancer Prev 19: 2613-2617, 2018.

9. Omuro A and DeAngelis LM: Glioblastoma and other malignant gliomas: A clinical review. JAMA 310: 1842-1850, 2013.

10. Graham J, Ramirez A, Love S, Richards M and Burgess C: Stressful life experiences and risk of relapse of breast cancer: Observational cohort study. BMJ 324: 1420, 2002.

11. Chida Y, Hamer M, Wardle J and Steptoe A: Do stress-related psychosocial factors contribute to cancer incidence and survival? Nat Clin Pract Oncol 5: 466-475, 2008.

12. Magnon C, Hall SJ, Lin J, Xue X, Gerber L, Freedland SJ and Frenette PS: Autonomic nerve development contributes to prostate cancer progression. Asian J Androl 15: 713-714, 2013.

13. Gray JD, Kogan JF, Marrocco J and McEwen BS: Genomic and epigenomic mechanisms of glucocorticoids in the brain. Nat Rev Endocrinol 13: 661-673, 2017.

14. Yang H, Xia L, Chen J, Zhang S, Martin V, Li Q, Lin S, Chen J, Calmette J, Lu M, et al: Stress-glucocorticoid-TSC22D3 axis compromises therapy-induced antitumor immunity. Nat Med 25: 1428-1441, 2019.

15. Volden PA and Conzen SD: The influence of glucocorticoid signaling on tumor progression. Brain Behav Immun 30 (Suppl): S26-S31, 2013.

16. Skor MN, Wonder EL, Kocherginsky M, Goyal A, Hall BA, Cai Y and Conzen SD: Glucocorticoid receptor antagonism as a novel therapy for triple-negative breast cancer. Clin Cancer Res 19: 6163-6172, 2013.

17. Thaker PH, Han LY, Kamat AA, Arevalo JM, Takahashi R, Lu C, Jennings NB, Armaiz-Pena G, Bankson JA, Ravoori M, et al: Chronic stress promotes tumor growth and angiogenesis in a mouse model of ovarian carcinoma. Nat Med 12: 939-944, 2006.

18. Park SY, Kang JH, Jeong KJ, Lee J, Han JW, Choi WS, Kim YK Kang J, Park CG and Lee HY: Norepinephrine induces VEGF expression and angiogenesis by a hypoxia-inducible factor- $1 \alpha$ protein-dependent mechanism. Int J Cancer 128: 2306-2316, 2011.

19. Radu M, Semenova G, Kosoff R and Chernoff J: PAK signalling during the development and progression of cancer. Nat Rev Cancer 14: 13-25, 2014.

20. Park MH, Lee HS, Lee CS, You ST, Kim DJ, Park BH, Kang MJ, Heo WD, Shin EY, Schwartz MA and Kim EG: p21-Activated kinase 4 promotes prostate cancer progression through CREB. Oncogene 32: 2475-2482, 2013.

21. Le CP, Nowell CJ, Kim-Fuchs C, Botteri E, Hiller JG, Ismail H, Pimentel MA, Chai MG, Karnezis T, Rotmensz N, et al: Chronic stress in mice remodels lymph vasculature to promote tumour cell dissemination. Nat Commun 7: 10634, 2016.

22. Na Z, Qiao X, Hao X, Fan L, Xiao Y, Shao Y, Sun M, Feng Z, Guo W, Li J, et al: The effects of beta-blocker use on cancer prognosis: A meta-analysis based on 319,006 patients. Onco Targets Ther 11: 4913-4944, 2018.

23. Lamkin DM, Sung HY, Yang GS, David JM, Ma JC, Cole SW and Sloan EK: $\alpha 2$-Adrenergic blockade mimics the enhancing effect of chronic stress on breast cancer progression. Psychoneuroendocrinology 51: 262-270, 2015.

24. Gao J, Liu X, Yang F, Liu T, Yan Q and Yang X: By inhibiting Ras/Raf/ERK and MMP-9, knockdown of EpCAM inhibits breast cancer cell growth and metastasis. Oncotarget 6: 27187-27198, 2015.

25. Das S: MDM2 Inhibition in a subset of sarcoma cell lines increases susceptibility to radiation therapy by inducing senescence in the polyploid cells. Adv Radiat Oncol 5: 250-259, 2020. 
26. O'Donnell JS, Massi D, Teng MWL and Mandala M: PI3K-AKT-mTOR inhibition in cancer immunotherapy, redux. Semin Cancer Biol 48: 91-103, 2018.

27. Jia X, Wen Z, Sun Q, Zhao X, Yang H, Shi X and Xin T: Apatinib suppresses the proliferation and apoptosis of gastric cance cells via the PI3K/Akt signaling pathway. J buon 24: 1985-1991, 2019.

28. Chen H, Zhou L, Wu X, Li R, Wen J, Sha J and Wen X: The $\mathrm{PI} 3 \mathrm{~K} / \mathrm{AKT}$ pathway in the pathogenesis of prostate cancer. Front Biosci (Landmark Ed) 21: 1084-1091, 2016.

29. Costa RLB, Han HS and Gradishar WJ: Targeting the $\mathrm{PI} 3 \mathrm{~K} / \mathrm{AKT} / \mathrm{mTOR}$ pathway in triple-negative breast cancer: A review. Breast Cancer Res Treat 169: 397-406, 2018.

30. Ediriweera MK, Tennekoon KH and Samarakoon SR: Role of the PI3K/AKT/mTOR signaling pathway in ovarian cancer: Biological and therapeutic significance. Semin Cancer Biol 59: 147-160, 2019.

31. Cui B, Luo Y, Tian P, Peng F, Lu J, Yang Y, Su Q, Liu B, Yu J, Luo X, et al: Stress-induced epinephrine enhances lactate dehydrogenase A and promotes breast cancer stem-like cells. J Clin Invest 129: 1030-1046, 2019.

32. Chen D, Tan Y, Li Z, Li W, Yu L, Chen W, Liu Y, Liu L, Guo L, Huang $\mathrm{W}$ and Zhao Y: Organoid cultures derived from patients with papillary thyroid cancer. J Clin Endocrinol Metab 106: 1410-1426, 2021.

33. Hu R, Li X, Peng C, Gao R, Ma L, Hu J, Luo T, Qing H, Wang Y, $\mathrm{Ge} \mathrm{Q}$, et al: miR-196b-5p-enriched extracellular vesicles from tubular epithelial cells mediated aldosterone-induced renal fibrosis in mice with diabetes. BMJ Open Diabetes Res Care 8: e001101, 2020.

34. Livak KJ and Schmittgen TD: Analysis of relative gene expression data using real-time quantitative PCR and the 2(-Delta Delta C(T)) method. Methods 25: 402-408, 2001.

35. Zhe D, Fang H and Yuxiu S: Expressions of hippocampal mineralocorticoid receptor (MR) and glucocorticoid receptor (GR) in the single-prolonged stress-rats. Acta Histochem Cytochem 28 41: 89-95, 2008

36. Zhang D, Ma Q, Shen S and Hu H: Inhibition of pancreatic cancer cell proliferation by propranolol occurs through apoptosis induction: The study of beta-adrenoceptor antagonist's anticancer effect in pancreatic cancer cell. Pancreas 38: 94-100, 2009.

37. Surman M and Janik ME: Stress and its molecular consequences in cancer progression. Postepy Hig Med Dosw (Online) 71: 485-499, 2017.

38. Umamaheswaran S, Dasari SK, Yang P, Lutgendorf SK and Sood AK: Stress, inflammation, and eicosanoids: An emerging perspective. Cancer Metastasis Rev 37: 203-211, 2018.

39. Zhang X,Zhang Y,He Z, Yin K, Li B,Zhang L and Xu Z: Chronic stress promotes gastric cancer progression and metastasis: An essential role for ADRB2. Cell Death Dis 10: 788, 2019.
40. Starr LR, Dienes K, Li YI and Shaw ZA: Chronic stress exposure, diurnal cortisol slope, and implications for mood and fatigue: Moderation by multilocus HPA-Axis genetic variation. Psychoneuroendocrinology 100: 156-163, 2019.

41. Verbeek E, Colditz I, Blache D and Lee C: Chronic stress influences attentional and judgement bias and the activity of the HPA axis in sheep. PLoS One 14: e0211363, 2019.

42. Kvetnansky R, Sabban EL and Palkovits M: Catecholaminergic systems in stress: Structural and molecular genetic approaches. Physiol Rev 89: 535-606, 2009.

43. Chetty S, Friedman AR, Taravosh-Lahn K, Kirby ED, Mirescu C, Guo F, Krupik D, Nicholas A, Geraghty A, Krishnamurthy A, et al: Stress and glucocorticoids promote oligodendrogenesis in the adult hippocampus. Mol Psychiatry 19: 1275-1283, 2014

44. Pistritto G, Trisciuoglio D, Ceci C, Garufi A and D'Orazi G: Apoptosis as anticancer mechanism: Function and dysfunction of its modulators and targeted therapeutic strategies. Aging (Albany NY) 8: 603-619, 2016.

45. D'Alterio C, Scala S, Sozzi G, Roz L and Bertolini G: Paradoxical effects of chemotherapy on tumor relapse and metastasis promotion. Semin Cancer Biol 60: 351-361, 2020.

46. Obradović MMS, Hamelin B, Manevski N, Couto JP, Sethi A, Coissieux MM, Münst S, Okamoto R, Kohler H, Schmidt A and Bentires-Alj M: Glucocorticoids promote breast cancer metastasis. Nature 567: 540-544, 2019.

47. Shin KJ, Lee YJ, Yang YR, Park S, Suh PG, Follo MY, Cocco L and Ryu SH: Molecular mechanisms underlying psychological stress and cancer. Curr Pharm Des 22: 2389-2402, 2016.

48. Butler DE, Marlein C, Walker HF, Frame FM, Mann VM, Simms MS, Davies BR, Collins AT and Maitland NJ: Inhibition of the PI3K/AKT/mTOR pathway activates autophagy and compensatory Ras/Raf/MEK/ERK signalling in prostate cancer. Oncotarget 8: 56698-56713, 2017.

49. Zhang H, Zhu Y, Sun X, He X, Wang M, Wang Z, Wang Q, Zhu R and Wang S: Curcumin-loaded layered double hydroxide nanoparticles-induced autophagy for reducing glioma cell migration and invasion. J Biomed Nanotechnol 12: 2051-2062, 2016.

50. Cole SW and Sood AK: Molecular pathways: Beta-adrenergic signaling in cancer. Clin Cancer Res 18: 1201-1206, 2012.

51. Homburger V, Lucas M, Rosenbaum E, Vassent G and Bockaert J: Presence of both beta1-and beta2-adrenergic receptors in a single cell type. Mol Pharmacol 20: 463-469, 1981.

52. Schwalbe T, Huebner H and Gmeiner P: Development of covalent antagonists for $\beta 1$-and $\beta 2$-adrenergic receptors. Bioorg Med Chem 27: 2959-2971, 2019.

53. O'Connor MD: The 3R principle: Advancing clinical application of human pluripotent stem cells. Stem Cell Res Ther 4: 21, 2013.

This work is licensed under a Creative Commons Attribution-NonCommercial-NoDerivatives 4.0 International (CC BY-NC-ND 4.0) License. 